\title{
Peningkatan Kompetensi Guru Melalui Lesson Study: Kasus Di Kabupaten Bantul
}

\author{
J.M. Tedjawati \\ tedjawatiks@yahoo.com, Pusat Penelitian Kebijakan, Balitbang Kemdiknas
}

\begin{abstract}
Abstrak: Tujuan penulisan ini dimaksudkan untuk mengetahui pelaksanaan program lesson study, khususnya dalam hal: 1) Pelaksanaan program lesson study; 2) Peran kepala sekolah dan kepala dinas pendidikan dalam pelaksanaan program lesson study; dan (3) Dampak pelaksanaan program lesson study. Temuan analisis ini menunjukkan bahwa: 1) Program lesson study dapat dilaksanakan karena adanya dukungan kerja sama antar guru, kepala sekolah, dan peran koordinator dalam menyusun program. Bagi guru, program ini sangat bermanfaat dalam pembelajaran di kelas, sekaligus dapat meningkatkan kemampuan kompetensinya. Guru dituntut untuk dapat melakukan perencanaan pembelajaran, mempraktikan pembelajaran tersebut, serta menerima masukan dari guru lain ataupun fasilitator atau kepala sekolahnya; 2) Adanya dukungan dari kepala sekolah dan kepala dinas pendidikan dalam program lesson study. Peran kepala sekolah antara lain dukungan dalam pelaksanaan, pendampingan, dan pendanaan kegiatan lesson study. Peran kepala dinas antara lain pemberian pelatihan dan sertifikat bagi guru, menyetujui penggunaan dana BOS untuk program lesson study; dan 3) Dampak program lesson study bagi guru adalah meningkatnya kemampuan guru. Mereka lebih inovatif dengan metode pembelajaran lebih bervariasi dan lebih relevan terhadap tingkat kemampuan siswa serta meningkatnya kualitas serta kuantitas guru dalam melaksanakan Penelitian Tindakan Kelas (PTK).
\end{abstract}

Kata kunci: kemampuan kompetensi guru, program lesson study

Abstract: The purpose of this writing is find out about the implementation of lesson study program, especially in terms of: 1) The implementation of lesson study program, 2) The role of school principals and heads of education offices in the implementation of lesson study program, and 3) The impact of the implementation of lesson study program. It's objective is to address the problems being faced today, to what extent the implementation of lesson study can be applied in the classroom and the impact of the lesson study program. Analysis findings show that: 1) Lesson study program can be implemented because of the support of cooperation between teachers, principals, and the role of coordinator in preparing the program. For teachers, the program is very useful in the classroom, while increasing the ability of competence. Teachers are required to be able to do lesson planning, teaching practice, as well as receive input from other teachers or facilitators, or principal, 2) The existence of support from school principals and heads of education offices in lesson study program. The role of principals, among others, support in the implementation, mentoring, and financing activities of lesson study. The role of head of educational office including the provision of training and certification for teachers, approved the use of the funds for lesson study program, and 3) The impact lesson study program for teachers is the increasing ability of teachers. They are more innovative in teaching with variety in the methods and more relevant towards student's ability. In addition, theachers quality and quantity increase in implementing the Classroom Action Research (PTK).

Key words: competency skills of teachers, lesson study program 


\section{Pendahuluan}

Dalam upaya meningkatkan mutu pendidikan nasional, pemerintah khususnya melalui Kementerian Pendidikan Nasional terus menerus berupaya melakukan berbagai perubahan dan pembaharuan sistem pendidikan. Salah satu upaya yang sudah dan sedang dilakukan, yaitu berkaitan dengan faktor guru. Peranan guru sangat menentukan dalam usaha peningkatan mutu pendidikan formal.

Undang-Undang Nomor 14, Tahun 2005 tentang Guru dan Dosen Pasal 4 menegaskan bahwa guru sebagai agen pembelajaran berfungsi untuk meningkatkan mutu pendidikan nasional. Guru mempunyai fungsi dan peran yang sangat strategis dalam pembangunan bidang pendidikan, oleh karena itu perlu dikembangkan sebagai profesi yang bermartabat. Untuk dapat melaksanakan fungsinya dengan baik, guru wajib untuk memiliki syarat tertentu, salah satu di antaranya adalah kompetensi.

Berbagai upaya untuk meningkatkan kualitas pembelajaran telah banyak dilakukan, baik oleh pemerintah maupun oleh berbagai pihak yang peduli terhadap pembelajaran di sekolah. Berbagai upaya tersebut antara lain dalam bentuk: 1) penataran guru; 2) kualifikasi pendidikan guru; 3) pembaharuan kurikulum; 4) implementasi model atau metode pembelajaran baru; dan 5) penelitian tentang kesulitan dan kesalahan siswa dalam belajar atau yang sering dilakukan guru seperti penelitian tindakan kelas. Salah satu kegiatan yang berkaitan dengan pembelajaran di sekolah adalah Lesson Study. Lesson study merupakan kegiatan kajian terhadap pelaksanaan pembelajaran yang dilaksanakan oleh guru. Lesson study bukan metode mengajar tetapi metode berbasis praktek, walaupun dalam kegiatan kajian pembelajaran tersebut, para guru pasti akan membicarakan metode mengajar, media, dan alat bantu pembelajaran yang digunakan dalam proses pembelajaran tersebut.

Lesson study diharapkan dapat dimanfaatkan semaksimal mungkin dalam kegiatan Kelompok Kerja Guru (KKG) dan Musyawarah Buru Mata Pelajaran (MGMP) sebagai upaya untuk menemukan proses pembelajaran yang dinilai paling efektif dan efisien untuk meningkatkan kualitas proses pembelajaran, yang pada gilirannya dapat berdampak, baik secara langsung maupun tidak langsung untuk meningkatkan hasil belajar siswa.

Permasalahan yang dihadapi saat ini adalah sampai seberapa jauh pelaksanaan lesson study dapat diterapkan dalam pembelajaran guru di kelas, bagaimana peran kepala sekolah dan kepala dinas pendidikan dalam pelaksanaan program lesson study, dan bagaimana dampak dari pelaksanaan program lesson study.

Tujuan penelitian ini dimaksudkan untuk memperoleh pengetahuan tentang program lesson study dalam: 1) Pelaksanaan program lesson study; 2) Peran kepala sekolah dan kepala dinas pendidikan dalam pelaksanaan program lesson study; dan 3) Dampak pelaksanaan program lesson study.

\section{Kajian Literatur Kompetensi Guru}

Kompetensi adalah pemilikan pengetahuan, keterampilan, kecakapan atau kemampuan sebagai seorang guru dalam menentukan atau memutuskan sesuatu berdasarkan kekuasaan yang dimilikinya agar proses pembelajaran dapat berjalan baik. Kompetensi dalam proses interaksi belajar mengajar dapat pula menjadi alat motivasi ekstrinsik, guna memberikan dorongan dari luar diri siswa (Pengertian Kompetensi Guru, http:// www.canboyz.co.cc/2010/06/pengertian-definisikompetensi-guru.html). Guru adalah orang yang bertugas sebagai pengajar dan pendidik bagi siswa. Guru sebagai orang yang berwenang dan bertanggung jawab terhadap pendidikan siswa, baik secara individual maupun secara klasikal baik di sekolah maupun di luar sekolah minimal harus memiliki dasar-dasar kompetensi sebagai wewenang dalam menjalankan tugasnya.

Pengertian kompetensi guru tersebut juga senada dengan pengertian kompetensi guru yang dikemukakan ahli lain bahwa kompetensi guru adalah kemampuan seorang guru dalam melaksanakan kewajiban-kewajibannya secara bertanggung jawab dan layak (Kompetensi Guru, http://rasto.wordpress.com/2008/01/31/ kompetensi-guru/). Jadi, kompetensi profesional guru dapat diartikan sebagai kemampuan dan kewenangan guru dalam menjalankan profesi keguruannya. Guru yang kompeten dan profesional adalah guru yang piawai dalam 
melaksanakan profesinya. Berdasarkan uraian di atas kompetensi guru dapat didefinisikan sebagai penguasaan terhadap pengetahuan, keterampilan, nilai dan sikap yang direfleksikan dalam kebiasaan berpikir dan bertindak dalam menjalankan profesi sebagai guru.

Undang-Undang Republik Indonesia Nomor 14, Tahun 2005 tentang Guru dan Dosen, mengisyaratkan bahwa guru adalah pendidik profesional dengan tugas utama mendidik, mengajar, membimbing, mengarahkan, melatih, menilai, dan mengevaluasi peserta didik pada pendidikan anak usia dini jalur pendidikan formal, pendidikan dasar, dan pendidikan menengah. Profesionalisme dalam pendidikan perlu dimaknai bahwa guru haruslah orang yang memiliki instink sebagai pendidik, mengerti dan memahami peserta didik. Guru harus menguasai secara mendalam minimal satu bidang keilmuan. Guru harus memiliki sikap integritas profesional. Kedudukan guru sebagai tenaga profesional sebagaimana dimaksud dalam Pasal 2 ayat (1) berfungsi untuk meningkatkan martabat dan peran guru sebagai agen pembelajaran berfungsi untuk meningkatkan mutu pendidikan nasional. Yang dimaksud dengan guru sebagai agen pembelajaran (learning agent) adalah peran guru antara lain sebagai fasilitator, motivator, pemacu, perekayasa pembelajaran, dan pemberi inspirasi belajar bagi peserta didik.

Kompetensi guru sebagaimana yang dimaksud dalam Pasal 8 Undang-Undang Republik Indonesia Nomor 14, Tahun 2005 meliputi kompetensi pedagogik, kompetensi kepribadian, kompetensi sosial, dan kompetensi profesional yang diperoleh melalui pendidikan profesi.

Kompetensi pedagogik merupakan kemampuan guru dalam mengelola pembelajaran, sekurang-kurangnya meliputi 1) pemahaman wawasan atau landasan kependidikan, 2) pemahaman terhadap peserta didik, 3) pengembangan kurikulum/silabus, 4) perancangan pembelajaran, 5) pelaksanaan pembelajaran yang mendidik dan dialogis, 6) pemanfaatan teknologi pembelajaran, 7) evaluasi proses dan hasil belajar, dan 8) pengembangan peserta didik untuk mengaktualisasikan berbagai potensi yang dimilikinya.

Kompetensi kepribadian sekurang-kurangnya mencakup 1) berakhlak mulia, 2) arif dan bijaksana, 3) mantap, 4) berwibawa, 5) stabil, 6) dewasa, 7) jujur, 8) mampu menjadi teladan bagi peserta didik dan masyarakat, 9) secara objektif mengevaluasi kinerja sendiri, dan 10) mengembangkan diri secara mandiri dan berkelanjutan.

Kompetensi sosial merupakan kemampuan guru sebagai bagian dari masyarakat, sekurangkurangnya meliputi 1) berkomunikasi lisan, tulisan, dan/atau isyarat, 2) menggunakan teknologi komunikasi dan informasi secara fungsional,3) bergaul secara efektif dengan peserta didik, sesama pendidik, tenaga kependidikan, pimpinan satuan pendidikan, orang tua/wali peserta didik, 4) bergaul secara santun dengan masyarakat sekitar dengan mengindahkan norma serta sistem nilai yang berlaku, dan 5) menerapkan prinsipprinsip persaudaraan dan semangat kebersamaan.

Kompetensi profesional merupakan kemampuan guru dalam menguasai pengetahuan bidang ilmu, teknologi, dan/atau seni yang sekurangkurang meliputi penguasaan 1) materi pelajaran secara luas dan mendalam sesuai standar isi program satuan pendidikan, mata pelajaran, dan/ atau kelompok mata pelajaran yang diampunya dan 2) konsep-konsep dan metode disiplin keilmuan, teknologi, atau seni yang relevan dan secara konseptual menaungi atau koheren dengan program satuan pendidikan, mata pelajaran, dan/atau kelompok mata pelajaran yang diampu.

Keempat kompetensi tersebut bersifat holistik dan integratif dalam kinerja guru. Oleh karena itu, secara utuh sosok kompetensi guru meliputi (a) pengenalan peserta didik secara mendalam; (b) penguasaan bidang studi baik disiplin ilmu (diciplinary content) maupun bahan ajar dalam kurikulum sekolah (pedagogical content); (c) penyelenggaraan pembelajaran yang mendidik meliputi perencanaan dan pelaksanaan pembelajaran, evaluasi proses dan hasil belajar, serta tindak lanjut untuk perbaikan dan pengayaan; dan (d) pengembangan kepribadian dan profesionalitas secara berkelanjutan.

Selanjutnya kompetensi guru dijabarkan dalam Peraturan Pemerintah Republik Indonesia Nomor 74 tahun 2008 tentang Guru Pasal 3 sebagai seperangkat pengetahuan, keteram- 
pilan, dan perilaku yang harus dimiliki, dihayati, dikuasai, dan diaktualisasikan oleh Guru dalam melaksanakan tugas keprofesionalan. Kompetensi guru tersebut meliputi kompetensi pedagogik, kompetensi kepribadian, kompetensi sosial, dan kompetensi profesional yang diperoleh melalui pendidikan profesi. Kompetensi pedagogik merupakan kemampuan guru dalam pengelolaan pembelajaran peserta didik. Oleh karenanya, guru dituntut untuk dapat meningkatkan kualitas pembelajaran di sekolah. Kualitas pembelajaran adalah kualitas kegiatan belajar mengajar yang dilakukan terkait dengan model pembelajaran yang digunakan.

\section{Pengertian Lesson Study}

Lesson Study dimulai di Jepang sekitar tahun 1870an. Lesson Study adalah metode berbasis praktik untuk mengembangkan profesionalisme guru dan sikap saling belajar dengan metode praktik sebenarnya di dalam kelas dan dilakukan oleh para guru itu sendiri (Project Activity, http://www. jica.go.jp/project/indonesian/indonesia/0800042/ activities/index.html). Lesson Study dibagi menjadi tiga bagian, yaitu perencanaan, observasi, dan refleksi (Gambar 1). Dalam sesi perencanaan, guru ataupun sekelompok guru merencanakan suatu pembelajaran; pada tahap observasi, satu orang guru melaksanakan pembelajaran berdasarkan rencana yang dibuat, sedangkan rekan-rekan yang lain melakukan observasi; dan selanjutnya guru yang mengajar bersama-sama dengan

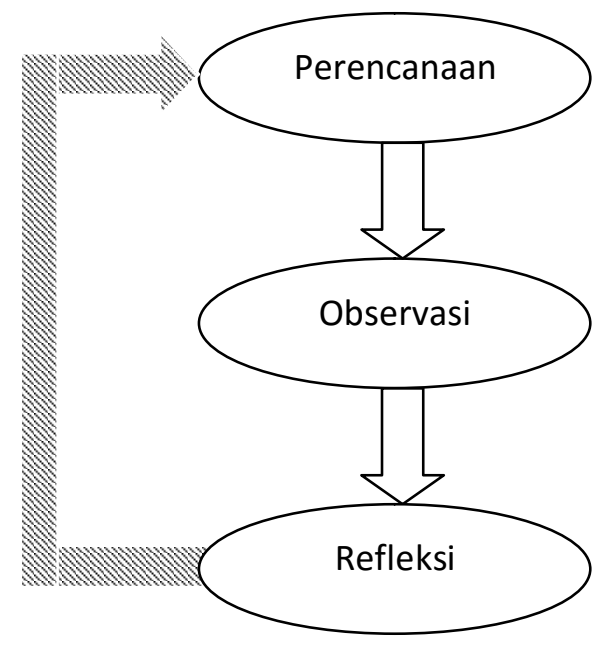

observer melakukan refleksi atas pembelajaran yang diamati.

Menurut Dr Ibrohim, dosen Fakultas MIPA dari Universitas Negeri Malang (Lesson Study dan Peningkatan Kompetensi Guru, http://www. suparlan.com/pages/posts/lesson-study-danpeningkatan-kompetensi-guru-263.php) "Lesson study adalah proses kegiatan pengkajian pembelajaran secara kolaboratif dan berkelanjutan berlandaskan prinsip-prinsip kolegialitas dan mutual learning untuk membangun learning community". Lesson study merupakan proses pengkajian pembelajaran dan dilakukan secara kolaboratif dan berkelanjutan. Lesson study dilakukan oleh kelompok guru yang sadar terhadap pentingnya upaya peningkatan kompetensi mereka dalam proses belajar mengajar. Para guru ini sadar bahwa proses pembelajaran yang selama ini telah dilaksanakan harus dikaji dari waktu ke waktu agar dapat lebih meningkat efektivitasnya bagi upaya untuk meningkatkan hasil belajar siswa. Harapan ideal yang ingin dicapai dalam kegiatan lesson study ini adalah membangun masyarakat belajar, sesuai dengan prinsip belajar sepanjang hayat (life long learning).

Lesson Study telah dikembangkan oleh Japan International Cooperation Agency (JICA) bekerja sama dengan pemerintah Indonesia sejak tahun 1998 di mana pada saat itu juga dikembangkan model Pengembangan Sekolah Berbasis Masyarakat (PSBM) di tingkat kabupaten. Model ini

Menyusun rencana pembelajaran (merancang pembelajaran)

Guru buka kelas melaksanakan pembelajaran, guru-guru lain mengamati

Guru-guru merefleksi pembelajaran bersama-sama 
bertujuan untuk mengembangkan kemampuan pemerintah daerah dan manajemen sekolah oleh berbagai pihak yang berkepentingan (stakeholder) seperti administrator pendidikan, kepala sekolah, guru, orang tua, dan masyarakat serta meningkatkan kemampuan guru untuk memperbaiki pembelajarannya. Melalui pengimplementasian model ini, telah banyak terlihat peningkatan manajemen sekolah dan peningkatan kualitas pendidikan di wilayah-wilayah sasaran, seperti meningkatnya komunikasi di antara para stakeholder, komitmen kepala sekolah dan guru semakin kuat, peningkatan pembelajaran, dan meningkatnya motivasi serta pemahaman siswa terhadap pelajaran.

\section{Pengembangan Lesson Study}

Selama ini Kementerian Pendidikan Nasional dan JICA sudah menjalin kerja sama dan hubungan yang baik lebih dari satu dekade (Sambutan Direktur Jenderal PMPTK, http://www.lesson studyindonesia.org/. Kerja sama yang telah dilakukan selama ini adalah kerja sama teknis dalam bidang peningkatan mutu pendidikan, terutama dalam hal peningkatan penguasaan mata pelajaran Matematika dan IImu Pengetahuan Alam (IPA) dan terangkum dalam urutan program: (1) Project for Development of Science and Mathematics Teaching for Primary and Secondary Education (IMSTEP, 1998-2003); (2) Program lanjutan IMSTEP (2003-2005); dan (3) Program for Strengthening In-service Teacher Training for Science and Mathematics (SISTTEMS, 2006-2008). SISTTEMS membidik semua guru Matematika dan IPA sekolah menengah pertama di tiga kabupaten dan merevitalisasi MGMP tingkat kabupaten dengan memperkenalkan Lesson Study.

Sejak Maret tahun 2009 sampai Maret tahun 2013 Pemerintah Republik Indonesia dan Pemerintah Jepang sepakat untuk memulai sebuah program kerja sama teknis untuk merumuskan upaya-upaya penyebarluasan model ini ke dalam pendidikan menengah pertama, yakni SMP dan MTs. Kerjasama teknis yang dinamakan "Program for Enhancing Quality of Junior Secondary Education" atau Program Peningkatan Kualitas SMP/MTs - selanjutnya disebut PELITA, bertujuan untuk melembagakan dan menyebarluaskan Pengembangan Sekolah Berbasis Masyarakat
(PSBM) dan Lesson Study (LS) melalui pembentukan struktur fungsional di tingkat nasional dan daerah.

Untuk lebih memahami implementasi lesson study yang lebih orisinil, berbagai tahap kegiatan telah dilakukan yaitu: 1) JICA memberi kesempatan bagi pejabat di lingkungan pendidikan dan agama untuk mengikuti pelatihan lesson study di Jepang; 2) Di tingkat nasional JICA dan Ditjen PMPTK telah memberikan pelatihan lesson study kepada widyaiswara LPMP, P4TK, Universitas, Guru, Kepala Sekolah, Pengawas Sekolah, dan Widyaiswara dari Balai Diklat Keagamaan Kementerian Agama. Sebanyak 480 orang yang telah dilatih ini akan menjadi narasumber potensial yang akan mendiseminasikan lesson study di sekolah-sekolah; 3) Di tingkat provinsi diadakan pelatihan lesson study di tiap-tiap LPMP. Mereka dilatih bagaimana mengelola dan melaksanakan lesson study di daerah mereka. Mereka dipersiapkan untuk mendampingi sekolah piloting lesson study hasil dari pemberian blockgrant peningkatan kompetensi pengawas dan kepala sekolah di daerah tertinggal. Tercatat sebanyak 203 sekolah SMP telah menjadi piloting lesson study pada tahun 2009; dan 4) Di tingkat kabupaten dan kota, sosialisasi dilakukan dengan menghadirkan pejabat kabupaten/kota, seluruh pengawas sekolah, kepala sekolah, guru, dan pihak universitas. Pada pertemuan ini, seluruh peserta yang hadir juga menyatakan komitmennya untuk mengimplementasikan lesson study di masing-masing daerahnya (Laporan Direktur Tenaga Kependidikan, http://www.lessonstudy indonesia. org).

Rangkaian kegiatan program PELITA ini adalah memberikan pelatihan kepada kepala sekolah tentang apa itu lesson study, bagaimana lesson study bekerja untuk meningkatan mutu pembelajaran di sekolah, bagaimana meningkatkan peran kepala sekolah dalam penjaminan kualitas yang berkesinambungan dalam kegiatan belajar mengajar, serta untuk meningkatkan pemahaman tentang PSBM. Pelaksanaan lesson study yang berpusat di sekolah lebih lanjut disebut Lesson Study Berbasis Sekolah (LSBS).

Selain LSBS, dikembangkan pula lesson study yang berpusat pada MGMP yang saat ini dikhususkan pada bidang Matematika dan IPA. Sebagai 
upaya pendukung LSBS ini, dilakukan pelatihan kepada fasilitator guru. Pelatihan yang disebut MGMP Facilitator Training ini bertujuan untuk memberikan pemahaman tentang lesson study dan menerangkan lebih teknis bagaimana lesson study dilakukan seperti memahami bagaimana cara melaksanakan buka kelas (open class), memahami bagaimana cara melaksanakan refleksi, dan bagaimana meningkatkan kualitas pembelajaran mereka sehari-hari. Pelatihan MGMP ini dilaksanakan dalam 3 seri pada tahun 2009 dan kurang lebih 240 orang fasilitator guru berpartisipasi aktif dalam pelatihan ini.

Ditjen PMPTK sangat meyakini bahwa Lesson Study bisa menjadi kendaraan untuk meningkatkan kualitas guru dengan didukung oleh kepala sekolah dan pengawas. Ini adalah sebuah kegiatan yang dapat meningkatkan kualitas KKG/ MGMP/Musyawarah Kerja Kepala Sekolah (MKKS), proses belajar mengajar, dan untuk mengimplementasikan KTSP. Aktivitasnya juga harus selalu dimonitor oleh Dinas Pendidikan kabupaten dan kota, LPMP, dan lembaga pendidikan terkait lainnya.

Implementasi lesson study ini berusaha untuk membentuk budaya saling memenuhi segala kekurangan. Oleh karena itu, rangkaian kegiatan selanjutnya adalah pelaksanaan lesson study pada homebase MGMP. Kegiatan ini dilakukan sebanyak 10 kali di setiap homebase-nya dan melibatkan 1.200 guru IPA dan Matematika di 3 daerah target baru. Kegiatan ini disebut MGMP Activities.

Keberhasilan penerapan lesson study sangat bergantung pada komitmen dan inisiatif kepala sekolah. Tanpa kerja keras mereka di bawah manajemen berbasis sekolah yang tertata apik, segala macam upaya para guru untuk mengimplementasikan lesson study akan menjadi sia-sia belaka. Menurut fakta-fakta yang ditemukan oleh Tim Ahli JICA di daerah referensi PELITA, lesson study dapat meningkatkan kepercayaan diri dan kompetensi guru dalam proses belajar mengajar mereka.

Metodologi yang digunakan dalam penulisan makalah ini adalah studi kasus. Yang dimaksud studi kasus adalah pendekatan yang memusatkan perhatian pada suatu kasus secara intensif dan rinci. Berkenaan dengan tulisan makalah ini maka program lesson study yang dijadikan fokus perhatian.

\section{Temuan Studi dan Pembahasan}

Pelaksanaan kegiatan lesson study

Program kegiatan lesson study dikembangkan di daerah kabupaten/kota antara lain di Kabupaten Bantul, yang ditunjuk sebagai percontohan pelaksanaan program LSBS dan lesson study dari JICA sejak tahun 2006 sampai tahun 2009 (termasuk pendanaan dari JICA). Lesson study ini khusus untuk mata pelajaran IPA dan Matematika. Tahun 2010 mulai dilaksanakan Proyek PELITA di kabupaten ini.

Selain lesson study yang dikhususkan pada mata pelajaran IPA dan Matematika, Dinas Pendidikan Kabupaten Bantul mulai mengimplementasikan lesson study untuk mata pelajaran Bahasa Inggris dengan dana Mandiri sejak tahun 2008. Dana Mandiri ini dimaksudkan bahwa pendanaan untuk kegiatan lesson study diambil dari dana Bantuan Operasional Sekolah (BOS). Hal ini sesuai dengan arahan Direktur Jenderal Manajemen Pendidikan Dasar dan Menengah (Ditjen Mandikdasmen), BOS bisa digunakan untuk kegiatan Lesson Study, namun di dalam pedoman BOS tidak secara khusus menyebutkan istilah "Lesson Study" karena ada beberapa sekolah yang masih belum mengenal istilah Lesson Study (Berita Proyek, http://www.jica.go.jp/ project/indonesian/indonesia/0800042/news/ general/100125.html).

Dinas Pendidikan Kabupaten Bantul telah menentukan hari MGMP untuk ketiga mata pelajaran tersebut yaitu hari Selasa untuk pertemuan MGMP Bahasa Inggris, hari Kamis untuk pertemuan MGMP matematika, dan hari Sabtu untuk pertemuan MGMP IPA. Pada hari pertemuan MGMP tersebut, para guru mata pelajaran tersebut diharuskan mengajar terlebih dahulu pada jam pelajaran pertama dan kedua di sekolahnya masing-masing. Setelah itu, mulai jam pelajaran ketiga para guru MGMP melakukan pertemuan di homebasenya masing-masing. Tempat penyelenggaraan MGMP bergantian tempat di dalam homebase yang sama. Setiap guru yang telah mengikuti pertemuan MGMP diharuskan dapat mensosialisasikan dan menerapkan Lesson Study untuk guru lain dari 
mata pelajaran lainnya.

Program lesson study dikelola secara bersama dengan para guru, namun ada seorang guru yang diangkat sebagai koordinator. Ada guru yang menyusun perencanaan pembelajaran, mempraktikan pembelajaran tersebut, dan menerima masukan dari guru lain. Koordinator juga merangkap sebagai fasilitator menyusun jadwal kegiatan lesson study berbasis MGMP dari tiga mata pelajaran (IPA, matematika, dan bahasa Inggris) untuk satu semester. Dalam jadwal tersebut sudah ditentukan sekolah-sekolah mana saja yang melakukan Perencanaan, Observasi, dan Refleksi (sebagai contoh lihat lampiran 1 jadwal dari bahasa Inggris SMP di Kabupaten Bantul). Berikut diuraikan tentang tiga tahapan dalam lesson study pada home base 2 mata pelajaran bahasa Inggris:

Tahap perencanaan dilaksanakan pada hari pertemuan MGMP, bertujuan unuk merancang pembelajaran yang dapat membelajarkan siswa dan berpusat pada siswa. Guru dari SMP PGRI Kasihan berkolaborasi merancang Rencana Pelaksanaan Pembelajaran (RPP), metode pembelajaran, media pembelajaran metode evaluasi, LKS, lembar observasi, denah tempat duduk siswa, pembagian kelompok, dan antisipasi terhadap permasalahan yang akan dihadapi.

Pada tahap observasi, guru mulai melaksanakan open class sesuai jadwal yang telah ditentukan dengan menerapkan RPP yang telah dirancang (pelaksanaan do di SMP 1 Pajangan). Guru penyaji melaksanakan proses pembelajaran di kelas yang biasa dilakukan. Dalam proses pelaksanaan pembelajaran ini, para pengamat mengamati proses pembelajaran, mulai dari membuka pelajaran, sampai dengan pelaksanaan pembelajaran dengan menggunakan metode dan media atau alat bantu pembelajaran, dan akhirnya sampai dengan menutup pembelajaran. Para pengamat melakukan pengamatan dan mencatatnya secara cermat.

Pada tahap refleksi dipimpin seorang moderator, melaksanakan refleksi terhadap pembelajaran, yaitu dengan mendiskusikan hasil pengamatan pembelajaran. Dalam diskusi ini, disampaikan tentang kelebihan yang telah dilakukan oleh guru penyaji, di samping kekurangan, bahkan kesalahan fatal yang telah dilakukan guru penyaji. Dalam pertemuan ini, para guru dapat mengambil simpulan tentang praktik terbaik yang telah dilakukan oleh guru penyaji, termasuk kekurangannya. Hasil simpulan ini sebaiknya disusun secara tertulis, dan kemudian disebarluaskan kepada guru-guru yang lain, terutama yang menjadi penyaji dan pengamat dalam kegiatan lesson study tersebut. Simpulan ini akan menjadi produk bersama yang amat bermanfaat untuk meningkatkan kompetensi para guru. Tahap refleksi sangat penting, karena di tahap ini semua guru akan mendapatkan banyak pengetahuan yang akan diimplementasikan di kegiatan pembelajaran selanjutnya di kelas masing-masing. Dengan demikian dapat dikatakan bahwa lesson study adalah inovasi tiada henti.

Pelaksanaan lesson study dapat berhasil dengan baik, apabila guru mengerjakan dan mempraktikan sekaligus mengimplementasikan di kelasnya tentang semua program lesson study yang telah diikuti di MGMP. Selain itu peran kepala sekolah sendiri yang memberi izin guru untuk ikut kegiatan MGMP, mengontrol dalam kehadiran guru dalam MGMP, memberi masukan pada saat dilakukan refleksi, dan terutama peran kepala sekolah yang memberikan dana untuk penyelenggaraan program lesson study.

Nara sumber Lesson Study di MGMP. Pada saat ini Fasilitator Trainer telah ditujuk sebagai pendamping pertemuan MGMP. Fasilitator ini telah mengikuti pelatihan tingkat kabupaten dan pelatihan di tingkat provinsi. Dosen dari Universitas Negeri Yogyakarta (UNY) mendampingi para guru dalam pertemuan MGMP secara rutin. Namun, sejak tahun 2009 dosen UNY tersebut tidak hadir secara rutin karena keterbatasan dana dari UNY sendiri untuk memberikan transport bagi dosennya. Sekolah juga tidak dapat menghadirkan dosen tersebut setiap pertemuan. Jika ingin mengundang dosen UNY maka sekolah diharapkan melapor terlebih dahulu kepada Dinas Pendidikan sebagai pemberitahuan.

Pendanaan Lesson Study di MGMP. Pada tahun tahun 2010, Kabupaten Bantul mendapat biaya stimulan dari Pemerintah Daerah sebesar Rp 750.000,- untuk setiap homebase dari setiap mata pelajaran IPA, matematika, dan bahasa Inggris. Tentu saja dana dari setiap homebase tersebut akan digunakan untuk penyelenggaraan MGMP 
dari sejumlah sekolah di tiap homebase. Selain itu, mata pelajaran bahasa Inggris mendapat bantuan blockgrant dari LPMP provinsi Yogyakarta sebesar Rp 15.000.000,- untuk tujuh homebase.

Pada pertemuan MGMP setiap sekolah melalui dana BOSnya mengeluarkan uang sebesar Rp 22.000,- untuk setiap guru yang hadir mengikuti pertemuan MGMP. Uang Rp 22.000,- tersebut dapat diberikan kepada guru yang bersangkutan dengan menyerahkan: 1) surat undangan pertemuan MGMP; 2) daftar hadir/absensi (fotocopynya); 3) kuitansi dari homebase; dan 4) notulen kegiatan MGMP. Daftar hadir tersebut harus diketahui oleh kepala sekolah dari tempat pertemuan MGMP. Namun, uang sebesar Rp 22.000,- tersebut tidak untuk setiap guru setelah dipotong pajak menjadi Rp 19.500,- dengan rincian: Rp 10.000,- untuk fotocopy dan snack di pertemuan dan Rp 9.500,- untuk transpor guru mengikuti pertemuan MGMP.

\section{Peran Kepala Sekolah Dan Kepala Dinas Pendidikan Kabupaten}

Kepala sekolah memegang peran yang sangat penting dalam keberhasilan program lesson study. Karena kepala sekolah harus mewajibkan para guru untuk melaksanakan semua tahapan dalam program lesson study mulai dari Plan, Do, dan See. Menurut kepala sekolah SMPN 1 Sewon, Kabupaten Bantul peran kepala sekolah sangat menentukan terhadap perencanaan, pelaksanaan, hasil, dan tindak lanjut kegiatan lesson study, karena kunci keberhasilan yang pertama adalah kesediaan kepala sekolah dalam memimpin dan mengelola komunitas pembelajaran, memaksimalkan seluruh sumber daya yang ada, mengefektifkan komunikasi antar-pribadi, pertukaran ide, dan kolaborasi bersama, mendukung seluruh staf untuk berpartisipasi dan berkomitmen, mengajak seluruh warga untuk dapat belajar dari permasalahan dan selalu berpikir positif, menciptakan keterbukaan, juga mengupayakan pendanaan yang diperlukan untuk pelaksanaan kegiatan lesson study dan tindak lanjutnya (Lesson Study Mengubah Pelaksanaan Pembelajaran Di SMP Negeri 1 Sewon, http://smp1sewonbantul.wordpress.com/ artikel/lesson-study-di-smp-1-sewon/).

Kepala sekolah berupaya untuk selalu hadir dalam kegiatan plan, do, dan see. Di SMP N 1 Sewon dari 51 kali kegiatan open class, sebanyak 45 kali kepala sekolah dapat hadir, dan 6 kali tidak dapat hadir karena ada tugas kedinasan yang tidak dapat diwakilkan. Dari 45 kali hadir di kegiatan open class kepala sekolah dapat memberi banyak masukan, saran, juga dapat belajar dari pembelajaran yang dilakukan para guru, sedangkan sebanyak 6 kali kepala sekolah tidak dapat hadir, dampaknya guru model menjadi kecewa. Oleh karena itu, kepada para kepala sekolah diharapkan agar ketika kegiatan open class diupayakan hadir dari awal sampai berakhirnya kegiatan refleksi, agar semua guru tetap semangat melaksanakan kegiatan lesson study. Peran Kepala Dinas Pendidikan tingkat kabupaten sangat menentukan keberhasilan dari program lesson study melalui berbagai kegiatan atau arahan yaitu 1) Pemberdayaan MGMP untuk melaksanakan program lesson study melalui pelatihan yang diberikan kepada fasilitator lesson study di mana fasilitator ini yang akan mendampingi para guru dalam melaksanakan program lesson study di sekolahnya; 2) Dukungan pendanaan pelatihan bagi fasilitator; 3) Disetujuinya penggunaan dana BOS untuk kegiatan lesson study melalui MGMP; dan 4) Komitmen Kepala Dinas Pendidikan dalam pemberian sertifikat bagi guru yang telah mengikuti program lesson study melalui tahap Plan, Do, dan See.

\section{Dampak Lesson Sudi}

Dampak yang terjadi pada guru setelah melaksanakan lesson study adalah adanya peningkatan kompetensi pedagogik, kompetensi profesional, kompetensi sosial dan kompetensi kepribadian, guru lebih inovatif, metode pembelajaran lebih bervariasi dan lebih relevan terhadap tingkat kemampuan siswa, guru tidak segan saling berbagi pengalaman dan ide, saling memotivasi dan mendapatkan umpan balik terhadap pembelajaran yang dilaksanakan, adanya kepuasan dan keikhlasan dalam bekerja, dan meningkatnya kualitas serta kuantitas guru dalam melaksanakan PTK (Penelitian Tindakan Kelas). Selain itu, melalui MGMP sejenis terjadi adanya keseragaman dalam pembelajaran mata pelajaran yang sama. 
Bagi siswa adanya program lesson study menyebabkan terjadinya peningkatan pemahaman terhadap materi pelajaran, peningkatan minat siswa terhadap mata pelajaran, peningkatan motivasi belajar, peningkatan keaktifan siswa dalam proses pembelajaran, tidak ada rasa cemas, siswa gembira, berani bertanya, lebih percaya diri, dapat bekerja sama dengan siswa lain dengan kelompoknya atau lintas kelompok, rasa ego berkurang, peningkatan efektivitas hasil belajar, dan adanya kepuasan dalam belajar.

Bagi sekolah adanya program lesson study menyebabkan terjadinya: 1) peningkatan nilai ujian yang membanggakan seperti yang dialami SMP N 1 Sewon sehingga mendapatkan penghargaan dari Bapak Bupati Bantul; 2) peningkatan prestasi akademik dan nonakademik dengan banyaknya kejuaraan yang diraih baik tingkat kabupaten, provinsi maupun nasional; 3) adanya peningkatan kepercayaan masyarakat dengan meningkatnya animo masyarakat yang mendaftarkan anaknya; 4) meningkatnya kepercayaan dari kolega dengan meningkatnya frekuensi studi banding ke sekolahnya; dan 5) meningkatnya kepercayaan pemerintah dengan meningkatnya bantuan yang diberikan kepada sekolah.

Menurut koordinator lesson study bahasa Inggris, para guru MGMP sejenis dapat menyusun bersama soal tes yang diperuntuk bagi siswa kelas IX dalam menghadapi Ujian Nasional. Selain dampak implisit yang dirasakan para guru, ada dampak eksplisit bagi guru yaitu adanya penerimaan sertifikat bagi guru yang telah mengikuti lesson study. Sertifikat tersebut ditandatangani oleh Kepala Dinas Pendidikan, diberikan setiap semester, dan berlaku nilainya untuk meningkatkan penilaian dalam sertifikasi guru. Dalam sertifikat tersebut dicantumkan jumlah jumlah jam yang diikuti dalam lesson study yang terdiri dari Plan, Do, dan See.

\section{Simpulan dan Saran Simpulan}

Program lesson study dapat dilaksanakan karena adanya dukungan kerja sama guru yang dilibatkan dalam program ini, adanya koordinator yang berperan sebagai fasilitator dan menyusun jadwal, adanya dana pendukung bagi penyelenggaraannya, serta dukungan kepala sekolah dan
Dinas Pendidikan Kabupaten. Selain itu, program ini sangat tepat dilakukan dalam kegiatan MGMP sehingga para guru dapat saling kerja sama, berbagi pengalaman dalam pembelajaran, serta dapat meningkatkan kemampuan kompetensinya.

Lesson study sangat bermanfaat bagi guru dalam pembelajaran di kelas, sekaligus dapat meningkatkan kemampuan kompetensinya Dalam lesson study guru dituntut untuk dapat melakukan perencanaan pembelajaran, mempraktikan pembelajaran tersebut, serta menerima masukan dari guru lain ataupun fasilitator atau kepala sekolahnya. Semua langkah dalam tahapan lesson study tersebut juga merupakan kemampuan guru dalam pengelolaan pembelajaran yang sering kali disebut kemampuan pedagogi. Semakin guru sering melakukan lesson study maka guru lebih inovatif dengan metode pembelajarannya lebih bervariasi dan lebih relevan terhadap tingkat kemampuan siswa.

Keberhasilan program lesson study tidak hanya berasal dari guru sendiri, melainkan juga karena adanya peran Kepala Sekolah dan Kepala Dinas Pendidikan tingkat kabupaten. Peran kepala sekolah dalam mendukung guru untuk melaksanakan lesson study mulai dari pemberian izin; mengontrol kehadiran; mementukan perencanaan, pelaksanaan, hasil, dan tindak lanjut kegiatan lesson study; memberi masukan dalam pembelajaran yang dilakukan guru, serta mengupayakan pendanaan yang diperlukan untuk pelaksanaan kegiatan lesson study dan tindak lanjutnya. Selain itu penting adanya peran kepala dinas pendidikan dengan memberikan pelatihan kepada fasilitator dalam pendampingan guru yang melaksanakan program lesson study, menyetujui penggunaan dana BOS untuk menunjang pelaksanaan lesson study melalui homebase MGMP serta berkomitmen untuk memberikan sertifikat bagi guru yang telah mengikuti lesson study.

Dampak yang dirasakan guru setelah melaksanakan program lesson study adalah meningkatnya kemampuan kompetensi pedagogi, kompetensi professional, kompetensi social dan kompetensi kepribadian. Guru lebih inovatif dengan metode pembelajaran lebih bervariasi dan lebih relevan terhadap tingkat kemampuan siswa. Guru tidak segan saling berbagi pengalaman dan 
ide, saling memotivasi dan mendapatkan umpan balik terhadap pembelajaran yang dilaksanakan, adanya kepuasan dan keikhlasan dalam bekerja, dan meningkatnya kualitas serta kuantitas guru dalam melaksanakan PTK. Bagi pihak sekolah, program lesson study dapat meningkatkan nilai ujian, prestasi akademik dan nonakademik, dan adanya kepercayaan masyarakat terhadap kemajuan/keberhasilan dari sekolah.

\section{Saran}

Keberhasilan program lesson study yang telah dilaksanakan di Kabupaten Bantul selama ini dengan dukungan para guru, kepala sekolah, dan Dinas Pendidikan, serta forum MGMP, dapat diterapkan pula oleh guru, kepala sekolah, dan dinas pendidikan di kabupaten/kota lain. Walau program ini menuntut adanya kerja sama berbagai pihak namun program ini juga dapat meningkatkan kemampuan profesionalisme guru serta mutu pendidikan.

Kemdiknas melalui kerja sama dengan JICA telah memperkenalkan program lesson study untuk memperkuat kompetensi kepala sekolah dan guru melalui pemberian bantuan teknis serta finansial di beberapa daerah. Kegiatan tersebut melibatkan para dosen universitas dan widya iswara LPMP. Oleh karenanya diharapkan penerapan program lesson study harus selalu dimonitor secara bersama oleh Dinas Pendidikan kabupaten dan kota, LPMP, dan lembaga pendidikan terkait lainnya. Kemdiknas harus menindak lanjuti temuan yang terjadi di daerah agar peningkatan mutu pendidikan dapat dicapai sesuai dengan rencana yang dicanangkan oleh pemerintah sendiri.

\section{Pustaka Acuan}

Berita Proyek: Pertemuan Komite Koordinasi Bersama di Jakarta. http://www.jica.go.jp/project/ indonesian/indonesia/0800042/news/general/100125.html diunduh pada tanggal 25 April 2011

Kompetensi Guru, http://rasto.wordpress.com/2008/01/31/kompetensi-guru/ diunduh pada tanggal 20 April 2011

Laporan Direktur Tenaga Kependidikan, http://www.lessonstudyindonesia.org. diunduh pada tanggal 29 April 2011.

Lesson Study Mengubah Pelaksanaan Pembelajaran Di SMP Negeri 1 Sewon, http:// smp1sewonbantul.wordpress.com/artikel/lesson-study-di-smp-1-sewon/ diunduh pada tanggal 5 Mei 2011

Lesson Study dan Peningkatan Kompetensi Guru, http://www.suparlan.com/pages/posts/lessonstudy-dan-peningkatan-kompetensi-guru-263.php). diunduh pada tanggal 8 Mei 2011

Pengertian Kompetensi Guru, http://www.canboyz.co.cc/2010/06/pengertian-definisi-kompetensiguru.html

Project Activity, http://www.jica.go.jp/project/indonesian/indonesia/0800042/activities/index.html diunduh 25 April 2011

Project for Development of Science and Mathematics Teaching for Primary and Secondary Education (IMSTEP, 1998-2003);

Program lanjutan IMSTEP (2003-2005);

Program for Strengthening In-service Teacher Training for Science and Mathematics (SISTTEMS, 20062008).

Undang-Undang Republik Indonesia Nomor 14, Tahun 2005 tentang Guru dan Dosen. 